Editorials

16 Surgical Treatment of Obesity

Weiner, R.A. (Frankfurt/M.)

2109 Editorial

Bittner, R. (Stuttgart); Böhmer, F. (Wien); Schmitz, R.

(Bergisch Gladbach)

3205 Hepatocellular Carcinoma - Where Do We Stand? Fleig, W.E. (Halle); Hauss, J. (Leipzig)

4301 Multimodal Treatment of Liver Metastases Klar, E. (Rostock)

Main Topics

Laparoscopic Adipositas Surgery

Herausgeber: R.A. Weiner, Frankfurt/M.

\section{Is Obesity a Disease?}

Hauner, H. (Düsseldorf)

112 Psychosomatics of Obesity

Schüler-Schneider, A. (Frankfurt/M.)

122 Obesity Surgery: History - Present - Future Husemann, B.J. (Düsseldorf)

130 Laparoscopically Implanted Adjustable Gastric Banding - Observations and Evolution Blanco-Engert, R.; Matkowitz, R. (Frankfurt/M.); Weiner, S. (Würzburg); Diaz Maag, R. (Merida); Weiner, R. (Frankfurt/M.)

135 Indication and Technique of the Adjustable Gastric Band

Müller, W.; Beller, S.; Szinicz, G. (Bregenz)

138 Treatment of GERD in Patients with Morbid Obesity a Case Report

Reijnen, N.P.M.; Shahbazian-Bscheidl, Z. (Leer)

141 Laparoscopic Vertical Gastroplasty - a New Approach for a Standard Procedure Bröhl, F. (Osnabrück)

146 Laparoscopic Roux-en-Y-Gastric Bypass - Technique and Complications

Weiner, R.A.; Blanco-Engert, R.; Winterberg, U. (Frankfurt/M.)
154 Laparoscopic Duodenal Switch - Technique and Initial Experience

Baltasar, A.; Bou, R.; Miro, J.; Bengochea, M.; Serra, C.;

Pérez, N. (Alcoy, Alicante)

157 Banded or Functional Gastric Bypass?

Weiner, R.A. (Frankfurt/M.)

162 Redo Surgery: Transformation of a Bariatric Treatment in Another

Weiner, R.A. (Frankfurt/M.)

170 Quality of Life after Bariatric Treatment - an Overview Weiner, S. (Würzburg); Weiner, R.A.; Pornhoff, I. (Frankfurt/M.)

\section{Surgery of the Elderly}

Herausgeber: R. Bittner, Stuttgart; F. Böhmer, Wien; R. Schmitz, Bergisch Gladbach

2110 Surgery in the Elderly - Introduction Busch, C.; Rehner, M.; Schreiber, H.W. (Hamburg)

2117 Anesthesia of Elderly Patients - Peculiarities and Diverse Methods Gonano, C.; Zimpfer, M. (Wien)

2124 Oncology: Characteristics of Elderly Patients Wedding, U.; Höffken, K. (Jena)

2131 Fecal Incontinence and Rectal Prolapse - Surgical Procedures to Restore or Improve Continence Lechner, M.; Langmayr, J.; Wunderlich, M. (Wien)

2136 Open Inguinal Hernia Repair and Conventional Cholecystectomy with Special Reference to the Elderly Schmitz, R.; Shah, S.; Metz, T.; Schmitz, U. (Bergisch Gladbach)

2142 Anesthesia in Laparoscopic Inguinal Hernia Repair Is There an Age Limit?

Hafner, C.; Schweizer, M.; Schmedt, C.; Däubler, P.; Jungigner, W. (Stuttgart)

2147 Laparoscopic Cholecystectomy - Outcomes in Elderly Patients

Ulrich, M.; Leibl, B.J.; Bittner, R. (Stuttgart)

2150 Laparoscopic Resection of Rectal Carcinomas in the Elderly

Bärlehner, E.; Roske, K.; Anders, S.; Benhidjeb, T. (Berlin)

\section{KARGER}

Fax +497614520714 (c) 2003 S. Karger GmbH, Freiburg Accessible online at:

E-mail Information@Karger.de www.karger.com/cga

www.karger.com 
2156 Surgical Treatment of Gastric Carcinoma - Are There Limitations in Elderly Patients?

Meyer, H.J.; Raab, C.; Opitz, G.J. (Solingen)

2164 Transnasal Feeding Tube or Percutaneous Endoscopic Gastrostomy for Nutrition of Elderly Patients Indications, Technique, Results Teleky, B.; Kührer, I.; Cosentini, E. (Wien)

\section{Hepatocellular Carcinoma}

Herausgeber: W.E. Fleig, Halle; J. Hauss, Leipzig

3207 Molecular Pathogenesis of Hepatocellular Carcinoma - State 2003

Ballhausen, H.G. (Halle)

3214 Epidemiology and Clinical Presentation of Hepatocellular Carcinoma Kubicka, S.; Manns, M.P. (Hannover)

3218 Baseline Imaging of Hepatocellular Carcinomas Bleck, J.S.; Kirchhoff, T.; Manns, M.P. (Hannover)

3225 Pathology of Hepatocellular Carcinoma Tannapfel, A.; Wittekind, C. (Leipzig)

3231 Interventional Therapy Options in Hepatocellular Carcinoma

Lotterer, E.; Göbel, C.-M. (Halle); Galandi, D.; Allgaier, H.-P. (Titisee-Neustadt); Fleig, W.E. (Halle)

3239 Surgical Therapy of Hepatocellular Carcinoma: When Resection, When Transplantation? Bartels, M.; Fangmann, J.; Hauss, J. (Leipzig)

3247 Hepatocellulary Carcinoma: Primary and Secondary Prophylaxis as well as Medical Therapy Fleig, W.E.; Lesske, J. (Halle)

3253 Gene and Immune Therapy of Hepatocellular Carcinomas: Facts and Fiction in 2003

Mohr, L.; Geissler, M.; Blum, H.E. (Freiburg i.Br.)

3261 Rational Diagnosis and Treatment of Hepatocellular Carcinoma

Fleig, W.E.; Dralle, H. (Halle)

\section{Multimodal Treatment of Liver Metastases}

Herausgeber: .E. Klar, Rostock; M. Birth, Lübeck

\section{Modern Diagnostic Management in Focal Lesions of the Liver \\ Hauenstein, K.; Heller, T. (Rostock)}

4315 Indication and Prognosis Factors in the Resection of Colorectal Liver Metastases

Scheele, J.; Altendorf-Hofmann, A. (Jena)
4324 Indication and Prognosis Factors in the Resection of Non-Colorectal Liver Metastases

Altendorf-Hofmann, A.; Scheele, J. (Jena)

4333 Standards of Surgical Techniques in Liver Metastases Rau, H.G.; Zimmermann, A.; Wardemann, C. (Dachau); Schildberg, F.W. (München)

4340 Surgical Therapy of Liver Metastases: Protection Strategies in Small Liver Remnant Hillert, C.; Lenk, C.; Mueller, L.; Krupski, G.; Rogiers, X.; Broering, D.C. (Hamburg)

4349 Interventional Therapy of Liver Metastases Birth, M.; Hildebrand, P.; Kleemann, M.; Bruch, H.P. (Lübeck)

4359 Radiation Therapy of Liver Metastases Herfarth, K.K.; Münter, M.C.; Debus, J. (Heidelberg)

4369 Chemotherapeutic Options of Liver Metastases Folprecht, G.; Köhne, C.-H. (Dresden)

4370 Regional Treatment for Unresectable Malignant Hepatic Tumors: An Overview of Isolated Hepatic Perfusion Ku, Y.; Tominaga, M.; Iwasaki, T.; Fukumoto, T.; Kusunoki, N.; Ogata, S.; Kuroda, Y. (Kobe)

\section{Integrated Therapy Strategy in Colorectal Liver Metastases Petrowsky, H.; Clavien, P.-A. (Zürich)}

Endoscopy in the Border Area between Gastroenterology and Visceral Surgery

Herausgeber: E.G. Hahn, Erlangen; R. Bittner, Stuttgart; J. Mössner, Leipzig; M. Büchler, Heidelberg

\section{S1 1 Editorial}

Hahn, E.G. (Erlangen); Bittner, R. (Stuttgart); Mössner, J. (Leipzig); Büchler, M.W. (Heidelberg)

S1 2 Endoscopy between Surgery and Gastroenterology the Point of View of the Chirurgische Arbeitsgemeinschaft für Endoskopie und Sonographie (CAES) Saeger, H.D. (Dresden)

S1 8 Frontiers and Transitions between Interventional Endoscopy and Abdominal Surgery Seifert, H. (Oldenburg)

S1 14 Training and Continuing Education in Gastrointestinal Endoscopy: What Must Be Demanded, What Are the Prerequisites?

Hochberger, J.; Maiß, J.; Hahn, E.G. (Erlangen)

S1 22 Concept of an Interdisciplinary Gastroenterology Visceral Surgical Ward Kramer, K.; Schönleben, M. (Ludwigshafen) 
S1 29 Endoscopy in Gastroenterology and Visceral Surgery: Independent Departments of Endoscopy? Pros and Cons

Mössner, J. (Leipzig)

S1 34 Endoscopy between Gastroenterology and Visceral Surgery - Point of View of an Universitary Visceral Surgical Center with an Own Endoscopic Department Schaible, A.; Singer, R.; Buhl, K.; Büchler, M.W. (Heidelberg)

S1 39 Division of Labor and Main Focus of Gastroenterologists and Visceral Surgeons Riemann, J. F. (Ludwigshafen)

S1 41 Development of a Consensus for the Fundamentals of Cooperation between Gastroenterologists and Visceral Surgeons

Fölsch, U. R. (Kiel)

S1 44 Endoscopy in the Border Area between Gastroenterology and Surgery - Point of View of a Specialized Hospital Rühland, D. (Singen)

S1 46 Donor-Recipient Conditioning in Organ Transplantations Jauch, K.-W. (München)

S1 51 Gastroenterology and Visceral Surgery a Memorandum Puts Joint Aims Beger, H.G. (Ulm)

S1 54 Basics of Cooperation between Gastroenterologists and Visceral Surgeons

Deutsche Gesellschaft für Verdauungs- und Stoffwechselkrankheiten, Deutsche Gesellschaft für Viszeralchirurgie

S1 56 Commentary of the Editors

Hahn, E.G. (Erlangen); Bittner, R. (Stuttgart); Mössner, J. (Leipzig); Büchler, M.W. (Heidelberg)

\section{Incisional hernias}

Herausgeber: R. Bittner, Stuttgart; M. Kux, Wien; R. Schlumpf, Aarau

S2 IV Editorial: Incisional Hernia Repair Bittner, R. (Stuttgart); Kux, M. (Wien); Schlumpf, R. (Aarau)

S2 1 Etiopathological and Pathophysiological Aspects of Incisional Hernias

Junge, K.; Rosch, R. (Aachen); Höer, J. (Düsseldorf); Klinge, U.; Stumpf, M.; Schumpelick, V. (Aachen)

S2 7 Requirements to an Ideal Mesh Implant Rosch, R.; Junge, K.; Stumpf, M.; Klinge, U.; Schumpelick, V.; Klosterhalfen, B. (Aachen)

S2 13 Laparoscopic Incisional Hernia Repair - the Diffulty of Fixation

Berger, D.; Bientzle, M. (Baden-Baden)
S2 16 Laparoscopic Incisional Hernia Repair - Is It Necessary that the Mesh Used in Intraperitoneal Onlay-Mesh Technique has Specific Characteristics? Benhidjeb, T.; Bärlehner, E.; Anders, S. (Berlin)

S2 24 Results of Conventional Mesh-Augmented Incisional Hernia Repair - Intraperitoneal Onlay Mesh, Onlay and Sublay Techniques

Lammers, B.J.; Voos, S.; Witt, M.; Goretzki, P.E. (Neuss)

S2 29 Biomechnics of the Abdominal Wall Hollinsky, C.; Hermann, M.; Glaser, K.S. (Wien)

S2 35 Onlay Technique in Hernia Surgery of Incisional Hernia Hollinsky, C.; Sandberg, S.; Glaser, K.S. (Wien)

S2 39 Retromuscular Prosthetic Mesh Implant of Incisional Hernias

Rosen, H.R.; Gyasi, A. (Wien)

S2 46 Closure of Ventral Giant Hernias through Modified Component Separation Technique

Schlüchter, R.; Hollmann, R.; Bühlmann, R.; Meuli-Simmen, C.; Schlumpf, R. (Aarau)

S2 51 Parastomal hernia Mesh Repair Using the Onlay Technique Sandera, P.; Wydler, J.A.; Schlumpf, R. (Aarau)

Interdisciplinary Discussions

176 Surgical Treatment of Obesity Husemann, B. (Düsseldorf) (Discussion Leader)

2173 Current Issues of Surgery on Elderly Patients - are Separate Standards Necessary? Schilling, M. (Homburg/Saar) (Gesprächsleiter)

\section{Hepatocellular Carcinoma} Klempnauer, J. (Hannover) (Discussion Leader)

4384 Multimodal Treatment of Liver Metastases Klar, E. (Rostock); Birth, M. (Lübeck) (Discussion Leaders)

Minimal Invasive Surgery

4391 Minimal Invasive, Endogastric, Endoscopically Assisted Resection of a Esophagogastric Gastrointestinal Stroma Tumor: Initial Experience Harms, J.; Schneider, A.; Roesch, T.; Böttcher, K. (München) 
Original Articles

181 Vascular Anatomy of the Front Abdominal Wall: A Contribution to Avoid Vessel Injuries during Laparoscopic Surgery

Balzer, K.M. (Düsseldorf); Witte, H. (Jena); Faustmann, P. (Bochum); Kozianka, J.; Waleczek, H. (Herne)

186 Self-Expanding Metal Stents in the Treatment of Colonic Obstruction

Dell'Abate, P.; Del Rio, P.; Colla, G.; Soliani, P.; Arcuri, M.F.; Ziegler, S.; Sianesi, M. (Parma)

189 Palliative Chemotherapy of Colorectal Cancer Results from an Inquiry

Manekeller, S.; Lauschke, H.; Tolba, R.; Minor, T. (Bonn); Gallkowski, U. (Neuwied); Hirner, A. (Bonn)

2176 Medical and Surgical Evaluation of Barrett's Esophagus and Barrett's Cancer Szentpáli, K.; Palotás, A.; Balogh, A.; Lázár, G. (Szeged)

3272 Metallic Stents in Malignant and Benign Biliary Obstruction: Retrospective Long-Term Results of Occlusion Rate, Complications and Reinterventions Pinocy, J.; Huppert, P.E.; Dudda, S.H. (Tübingen); Brambs, H.-J. (Ulm); Becker, H.D.; Clausen, C.D. (Tübingen)

4396 Laparoscopic versus Open Appendectomy: Analysis of Systemic Acute-Phase Responses in a Prospective Randomized Study Karadayi, K.; Turan, M.; Canbay, E.; Topcu, O.; Sen, M. (Sivas)

Case Reports

2181 Intraluminal Migation of Retained Surgical Sponge without Sign of Peritonitis - Report of a Case Turan, M. (Sivas); Kibar, Y. (Ankara); Karadayi, K. (Sivas); Kilicarslan, H. (Ankara); Sen, M. (Sivas)

2184 Acute Cholecystitis, Obstructive Jaundice, Pyogenic Cholangitis, and Acute Pancreatitis Caused by Ascaris lumbricoides: Report of a Case Karadayi, K.; Canbay, E.; Turan, M.; Gökgöz, S.; Sen, M. (Sivas)

2187 Retrorectal Tumor - a Rare Disease Strupas, K.; Stasinkis, A. (Vilnius)

3279 Primary Carcinoma of the Appendix and Its Management - a Case Report Voboril, R.; Pospís ili, I.; Dvorák, J. (Hradec Kralove)
3283 Chronic Pancreatitis, Covered Perforation of the Duodenal Wall and Breakage of the Bile Duct Stent Gottschalk, U.; Casper, B.; Boden, G. (Berlin)

4401 Pneumatosis Cystoides Intestinalis Associated with Duodenal Ulcer and Pyloric Stenosis: Report of Two Cases

Turan, M.; Karadayi, K.; Koyuncu, A.; Duman, M.; Ceran, T.; Sen, M. (Sivas)

Professional Education

2190 Surgical Education in Lithuania Strupas, K. (Vilnius)

Letter to the Editors

196 Improved Early Detection of Gastric Cancer Classen, M. (Gastro-Liga); Riemann, J.F. (Lebensblicke); Schmiegel, W.-H. (DGVS)

Innovations

2 196, 3290,4409

Book Reviews

199, 2 193, 3286,4404

Meetings and Conferences

1 101, 2 199, 3 292, 4412

4415 Author Index Vol. 19, 2003

4419 Subject Index Vol. 19, 2003 